\title{
MANAJEMEN REFERENSI DAN GAYA PENULISAN PUSTAKA
}

\section{A. Manajemen Referensi}

Dalam dunia penulisan ilmiah, kejujuran merupakan salah satu tolak ukur kualitas. Untuk memperlihatkan kejujuran tersebut, penulis akan merujuk kepada sekian banyak bahan bacaan dan menampilkan sebagian kalimat sebagai pernyataan penulis lain yang mendukung ide dalam tulisannya.

Keberadaan referensi pada tulisan ilmiah merupakan sebuah keharusan dalam karya ilmiah.Referensi merupakan aspek yang sangat penting dalam dunia akademis.Seorang akademisi tentunya tidak dapat dipisahkan dari buku, jurnal, artikel dan makalah.Tidak terlalu mengherankan bila seorang akademisi memiliki referensi dengan jumlah hampir satu ruangan kerja bahkan lebih (Handoko, 2016).

Di samping faktor buku, jurnal atau karya ilmiah lain terlewatkan, faktor Inkonsisten penulisan juga sering dijumpai pada saat penulisan bibliografi. Seringkali penulis menulis kota penerbit sebuah buku sebelum nama penerbit pada satu kutipan bibliografi, namun pada kutipan lain kota penerbit ditulis setelah nama penerbit buku. Hal tersebut juga dijumpai terhadap aturan penulisan-penulisan author, volume jurnal dan halaman yang tidak konsisten ditulis dalam satu bibliografi.

Hal lain yang sering terjadi, ketika penulis buku mengadakan pengeditan terhadap karya tulisnya. Sebagai contoh penulis menghapus suatu baris atau kalimat karena di rasa tidak pas dengan alasan lain. Secara otomatis sumber rujukan seperti author dan tahun dihapus. Namun penulis terkadang lupa untuk menghapus di bagian bibliografi, sehingga mengakibatkan, ada satu atau dua buah kutipan di bibliografi yang tertulis tapi tidak dapat ditelusur di bagian in text.

Untuk menghindari hal tersebut di atas, maka penulis suatu karya ilmiah yang banyak melakukan penyitiran, sangat disarankan melakukan manajemen referensi. Dalam melakukan manajemen referensi sekarang ini penulis banyak dibantu dengan kehadirankehadiran piranti lunak untuk manajemen referensi. Masing-masing piranti lunak manajemen referensi tersebut punya kelebihan dan kekurangan tersendiri (Nugroho, 2015)

Referensi merupakan hal yang paling penting bagi calon penulis dalam mengembangkan tulisannya.Tulisan yang baik dapat dinilai dari referensi yang digunakan.Pencarian dan pengumpulan referensi membutuhkan waktu yang lama dan tenaga yang cukup besar dengan tingkatan dan konsentrasi yang tinggi untuk menulis sumber tulisan agar tidak disebut plagiat.

Meskipun secara sederhana, software yang kita gunakan menulis seperti Ms. Word telah dilengkapi dengan Bibliografi namun penggunanya kurang diminati dan jarang 
digunakan dibandingkan dengan software manajemen referensi yang benar-benar dibuat untuk memudahkan penulis dalam mengolah referensi seperti Mendeley, Zotero, dan Endnote.

Software manajemen referensi yang paling sering digunakan pada kalangan akademisi, Mahasiswa, peneliti maupun masyarakat umum yang bergelut dengan karya tulis ilmiah dan buku-buku acuan adalah Endnote, meskipun membutuhkan dana yang tidak sedikit untuk bisa menggunakannya (Kistan, 2018)

Menggunakan perangkat lunak bibliografi seperti manajemen referensi atau software menata format referensi, seperti BibTeX untuk dokumen LaTeX, Endnote atau RefWorks. Perangkat lunak ini akan membantu penulis memfermat bagian referensi yang ditulisnya dengan mudah. Pada saat penulis akan membuat perubahan untuk bagian referensi tertentu, maka akan mudah untuk mengatur ulang susunan format yang berbeda. sistem perangkat lunak ini juga dapat membantu dengan mengelola perpustakaan yang berisi kutipan, PDF, dan file gambar. Hal ini memungkinkan penulis untuk mengatur naskah penting dengan subjek dan pencarian kepustakaan menggunakan kata kunci.

Perangkat lunak untuk manajemen referensi, perangkat lunak bibliografi atau personal perangkat lunak manajemen bibliografi adalah perangkat lunak yang digunakan penulis untuk merekam dan memanfaatkan kutipan bibliografi (referensi).

Pengembangan perangkat lunak manajemen referensi telah didorong oleh ekspansi yang cepat dari literatur ilmiah. Paket manajemen referensi yang modern biasanya dapat diintegrasikan dengan pengolah kata sehingga daftar referensi dalam format yang sesuai dihasilkan secara otomatis sebagai sebuah artikel yang ditulis, mengurangi resiko bahwa sumber dikutip tidak termasuk dalam daftar referensi (Fatchiyah, 2016)

Istilah referensi berasal dari bahasa inggris to refer yang artinya menunjuk.Sedangkan referensi menurut Kamus Besar Bahasa Indonesia (KBBI) adalah sumber, acuan, rujukan atau petunjuk.Di dalam ilmu perpustakaan istilah referensi berarti menujuk kepada suatu koleksi yang dapat menjawab pertanyaan yang diajukan oleh pemakai perpustakaan. Untuk koleksi referensi biasanya ditempatkan diruang tersendiri yang dinamakan ruang referensi dan untuk bukunya diberi tanda “ $R$ ” atau tulisan Ref, singkatan dari kata rujukan atau referensi, buku referensi merupakan buku referensi merupakan buku yang dapat memberikan keterangan tentang suatu topik, nama orang, tempat, istilah, riwayat dari orang-orang terkenal dan lain sebagainya (Kalsum, 2016).

\section{Software Manajemen Referensi}

Software manajemen referensi memiliki beberapa fungsi. Pertama untuk mencari, 
menyimpan, mencari (di komputer), dan membacanya. Fungsi ini mirip seperti katalog perpustakaan. Ketika koleksi buku terdaftar pada katalog, maka jumlah yang banyak, dan letak koleksi yang tersebar tidak akan menjadi masalah ketika dilakukan proses pencarian. Ketika menggunakan software manajemen referensi juga demikian. Cukup dilakukan pencarian melalui satu antarmuka saja.

Fungsi berikutnya, software ini digunakan untuk membantu membuat kutipan dan daftar pustaka. Software ini akan membantu mendapatkan sumber kutipan, dan menempatkannya dalam daftar pustaka. Jumlah sumber yang dikutip dan daftar pustaka yang tersusun akan sama, tidak selisih. Fungsi terakhir, untuk berjejaring. Fungsi ini ada yang digunakan semuanya, atau yang diperlukan saja.

2. Zotero,

Zotero, dapat dipasang pada sistem operasi Windows, Linux maupun Mac. Zotero dapat diunduh secara bebas. Ada beberapa hal yang akan dibahas mengenai Zotero:

a. Setting files and folder

Penentuan folder ini digunakan untuk penyimpanan file yang dikelola dengan Zotero yang dimasukkan ke Zotero dengan mode "Store Copy of File", serta penentuan letak penyimpanan database metadata file (judul, pengarang, penerbit, nama jurnal, dll).

Setting ini dilakukan melalui Edit-> Preference-> Advance-> File and Folder. Kemudian ganti folder dengan folder baru yang dibuat, ingat letak folder jangan di C.

Selain itu, setting berikutnya ada di “Search". Install plugin pdftotext dan pdfinfo dengan cara klik install. Setelah dua hal tersebut dilakukan, sudah bisa menggunakan Zotero untuk manajemen referensi.

b. Memasukkan dokumen

Setelah itu harus memasukan dokumen referensi kita ke Zotero, agar nanti mudah dicari. Ada dua jenis, pertama file digital, yang kedua tercetak.

PERHATIAN; untuk lebih aman, dokumen digital yang hendak dikelola menggunakan Zotero, letakkan dahulu di tempat yang aman, bukan di drive C. Misalnya D://ARTIKEL, atau tempat lainnya.

Untuk versi digital, dapat memasukkannya ke Zotero dengan cara klik icon (+) kemudian pilih “Store copy of file”, jika ingin memasukkan data dokumen ke Zotero, sekaligus menyalin file ke folder yang sudah diseting. Atau "Link to file", jika ingin file tetap ada di tempat aslinya, namun metadata disimpan oleh Zotero.

Kemudian, lakukan klik kanan pada dokumen, lalu pilih “retrive for metadata PDF”. 
Jika berhasil, maka Zotero akan menemukan metadata dan disimpan dalam databasenya.

Untuk dokumen tercetak, ketika akan menggunakan Zotero untuk membuat kutipan dan daftar pustaka. Kekeliruan di metadata pada Zotero harus diperiksa.

c. Melakukan pencarian pada database Zotero

Setelah file dan metadata selesai, maka dimanapun letak file, akan dapat dilakukan pencarian melalui tampilan Zotero.

d. Memasang RSS

RSS merupakan kepanjangan dari Really Simple Sindication. RSS dapat digunakan untuk memanggil jurnal atau pencarian tertentu dari sebuah database. Hasil pencarian, ditampilkan pada aplikasi pembaca RSS.

URL RSS dapat diperoleh dari berbagai sumber. Misalnya ingin mengambil dari RSS jurnal di Sciencedirect. Maka dapat dilakukan langkah sebagai berikut:

- Masuk ke sciencedirect.com

- Cari jurnal tertentu

- Klik jurnal tersebut

- Pilih RSS ke semua atau hanya open access saja, lalu klik pilihannya

- Beri nama RSS-nya

- Salin URL RSS yang diberikan

- Masuk ke Zotero

- Tambah RSS, dan temple URL RSS

e. Memasang Plugin Browser

Plugin pada browser, dapat dimanfaatkan untuk menyimpan informasi pada laman web html Wikipedia, metadata buku dari Amazon.com, dari sciencedirect.com, dan lainnya. Termasuk dari blog, atau website institusi.

f. Mengutip dan membuat daftar pustaka

Fungsi ini membantu pengguna Zotero dalam menuliskan sumber kutipan dan daftar pustaka.

Sumber kutipan yang ditulis, dapat diletakkan di awal, tengah maupun akhir. Zotero mampu memformat pada ketiga tempat tersebut. Kutipan yang dibuat, hanya bisa dilakukan dari metadata yang sudah masuk di Zotero. Kutipan dilakukan melaui Ms. Word atau LibreOffice. Namun bisa juga dilakukan di $L^{A} T E^{X}$ melalui database.bib.

Daftar pustaka yang disusun menggunakan Zotero, diambilkan dari sumber kutipan 
yang telah disusun pula menggunakan Zotero. Daftar pustaka dapat ditempatkan pada tempat yang diinginkan, menggunakan berbagai format (gaya) penulisan.

Untuk mengutip, dilakukan dengan cara klik Add/Edit Citation.

Selanjutnya, pilih dokumen yang hendak dijadikan sumber kutipan, dengan cara menuliskan pengarang atau judul.

Jika telah dipilih, tekan ENTER, maka akan muncul sumber kutipan pada teks. Untuk menampilkan sumber kutipan pada daftar pustaka, klik Add/Edit Bibliography.

Gaya penulisan kutipan dan daftar pustaka, dapat diganti sesuai kebutuhan. Daftar lengkap gaya tersebut dapat dilihat di zotero.org/styles. Gaya yang ada pada daftar tersebut, dapat dipasang pada Zotero, sehingga dapat digunakan.

g. Membuat cadangan data

Pada Zotero, terdapat dua jenis dokumen yang harus dicadangkan. Pertama data dari file yang berupa metadata identitas tiap dokumen yang disimpan, mulai dari jenis, judul pengarang, penerbit dan seterusnya. Kedua, file digital dan dokumen (jika ada).

Dua dokumen tersebut dapat diatur dan diletakkan dalam satu tempat. File berakhiran .sqlite merupakan file tempat metadata disimpan, sedangkan folder stroge merupakan folder tempat penyimpan file dokumen. Karena keduanya ada dalam satu tempat, maka cadangan dapat dilakukan dengan cara menyalin folder tersebut, atau menyingkronkannya pada Dropbox, GoogleDrive, atau layanan Cloud lainnya.

Selain itu, Zotero dapat melakukan pencadangan dalam layanan cloud Zotero. Namun, layanan ini (yang disediakan gratis) hanya berkapasitas 300MB. Hanya membayar dengan biaya tertentu. (Purwoko, 2017)

\section{Jurnal Elektronik}

Informasi diperlukan dalam melakukan sebuah penelitian, sebuah informasi yang digunakan harus informasi ilmiah, ketersediaan informasi ilmiah memiliki hubungan erat dengan sumber informasi, sistem komunikasi ilmiah, dan cara memperoleh informasi tersebut.

Sumber referensi mengikuti perkembangan teknologi sehingga pada saat ini sumber referensi tersedia dalam bentuk digital.Bentuk digital tidak terlepas dari keberadaan jaringan internet yang mendukung keberadaan sumber referensi digital dan berdampak luar biasa dalam perkembangan informasi.

Sumber referensi digital dapat berupa buku elektronik dan jurnal elektronik.Sumber 
informasi berbasis internet tersedia sepanjang waktu, terlepas dari waktu buka perpuastakaan, dan tidak rentan terhadap pencurian atau kerusakan, serta mudah diperbaharui oleh penerbit, dan internet merupakan sumber utama mahasiswa dalam pencarian informasi.Untuk sumber referensi, ketersediaan informasi yang mutakhir sangat dibutuhkan oleh para peneliti.Informasi pada jurnal elektronik yang lebih mutakhir berisi artikel-artikel dari hasil penelitian yang terbaru dan aktual.Sumber referensi elektronik tetap mempertahankan karakteristik dari referensi tercetaknya. Jurnal elektronik sebagai sumber referensi dalam penulisan skripsi membuat nilai tambahan informasi yang relevan tentang penelitian yang diambil (Amaliah, 2017)

\section{Mendeley}

Sebelum menggunakan mendeley, kita harus mengetahui fungsi daripada mendeley. Mendeley adalah software manajemen referensi dan jaringan sosial akademis yang bisa membantu kita mengorganisir publikasi hasil penelitian, menulis skripsi, tesis, desertasi, dan berkolaborasi dengan peneliti lain secara online serta menemukan publikasi penelitian terkahir. Mendeley merupakan program komputer dan web yang dikembangkan Elsevier untuk mengelola dan berbagi makalah penelitian, mencari data penelitian, dan bekerjasama secara daring. Mendeley menggabungkan mendeley desktop, perangkat lunak manajemen referensi dan PDF, dengan mendeley android and Ios dan mendeley web, jejaring sosial peneliti.sebagai database referensi, file referensi seperti buku atau artikel dari jurnal dalam bentuk PDF bisa disimpan dan diberi keterangan yang tepat untuk membantu mempermudah pencarian file-file PDF yang disimpan juga bisa dibuka, dibaca, dan diberi catatan-catatandengan sticky notes atau highlight. Tulisan yang dibuat dengan Microsoft Word, Open Office atau Latex bisa dihubungkan dengan software mendeley sehingga sitasi dan daftar referensi (bibliography) bisa disusun secara otomatis. Mendeley juga bisa dihubungkan dengan software manajemen referensi lainnya seperti Endnote, Papers dan Zotero.

Mendeley sebagai program aplikasi yang berdiri sendiri dan gratis guna mengelola keputakaan dan mengembangkan jejaring sosial akademik yang bermanfaat, saling berbagi kepustakaan secara daring, dan mencari keputakaan terkini.

Setelah mengintal, diperlukan plugin untuk Microsoft Word dari menu Tools program Mendeley agar dapat digunakan untuk pengutipan secara otomatis pada saat menulis makalah. Selain untuk mengelola kepustakaan, Mendeley dapat digunakan juga untuk menyimpan berkas (file) pustaka yang diunduh dalam format PDF dan memberikan anotasi (catatan dan tanda khusus tertentu) dalam berkas PDF tersebut.

Menerapkan berbagai gaya referensi yang berbeda dalam setiap bidang ilmu dengan 
menggunakan aplikasi Mendeley tidak perlu lagi dilaksanakan secara manual. Dengan aplikasi ini, pengguna cukup memilihnya saja pada saat membuat pangkalan data kepustakaan dan gaya yang dipilih akan dengan sendirinya digunakan pada saat akan dikutip. Kelebihan dari aplikasi ini ialah tidak perlu lagi mengetik daftar pustaka. Mendeley akan secara otomatis menyusun daftar pustaka begitu telah selesai menyitasi atau mengutip.

Tahap pertama yang perlu dilakukan untuk memanfaatkan aplikasi ini dalam penulisan karya tulis ilmiah adalah menyusun data pustaka di dalam library Mendeley. Proses impor dapat dilakukan dengan beberapa cara. Pada dasarnya bila sumber pustaka tersedia dalam format digital (berkas yang disertai dengan metadata) akan sangat mudah dikenali data pustakanya oleh aplikasi ini.

Tahap selanjutnya adalah mulai menulis, mengutip sitasi, dan membangkitkan daftar pustaka di aplikasi MS Word Office. Untuk tahap ini tidak lagi diperlukan koneksi internet. Kemampuan lain dari mendeley adalah memungkinkan pengguna untuk berbagi pangkalan data secara daring dengan pengguna lainnya. Dengan demikian, terbangun jejaring (networking) yang luas, atau disebut juga dengan jejaring sosial untuk akademik (Lukman, 2017)

\section{B. Gaya Penulisan Pustaka}

Bagian dari upaya untuk menghindari plagiarisme adalah dengan memahami berbagai model sitasi, cara membuat sitasi (kutipan) dan menuliskan daftar pustaka. Pengetahuan ini penting, ketika kita akan membuat suatu karya ilmiah. Menuliskan sitasi (kutipan) merupakan bentuk pengakuan terhadap pengarang, karena ide,gagasan, pendapat atau bahkan teorinya telah kita gunakan, untuk mendukung atau melengkapi pendapat, ide kita dalam sebuah karya tertentu. Sitasi atau kutipan tidak saja penting sebagai bentuk informasi kepada sumber aslinya, akan tetapi lebih pada bagaimana pengembangan pengetahuan itu dibangun melalui tulisan tulisan yang saling terkait. (Istiana, 2013)

\section{$>$ Ketentuan Mengenai Pengutipan}

Kutipan adalah bagian dari pernyataan, pendapat, buah pikiran, definisi, atau hasil penelitian orang lain atau penulis sendiri yang telah terdokumentasi. Kutipan akan dibahas dan ditelaah berkaitan dengan materi penulisan. Kutipan dari pendapat berbagai tokoh merupakan esensi dalam penulisan sinteisis. Kutipan dilakukan apabila penulis 
sudah memperoleh sebuah kerangka berpikir yang mantap. Walaupun kutipan atas pendapat seorang pakar itu diperkenankan, tidaklah berarti bahwa keseluruhan sebuah tulisan dapat terdiri dari kutipankutipan. Garis besar kerangka karangan serta kesimpulan yang dibuat harus merupakan endapat penulis sendiri. Kutipan-kutipan hanya berfungsi sebagai bahan bukti untuk menunjang pendapat penulis.

Manfaat Kutipan:

- untuk menegaskan isi uraian

- $\quad$ untuk membuktikan kebenaran dari sebuah pernyataan yang dibuat oleh penulis

- untuk mencegah penggunaan dan pengakuan bahan tulisan orang lain sebagai milik sendiri (Wasmana, 2011)

1. Mengutip Langsung.

Mengutip langsung dapat dilakukan dengan menggunakan tanda petik dua pada bagian kaliamat atau frasae yang dikutip.Perlu diperhatiakan jika melakukan kutipan langsung, sehingga kutipan langsung tersebut tidak menjadi bagian yang dominan dalam suatu karya. Artinya karya tersebut tidak sekedar hanya kumpulan kutipan dari berbagai sumber. Kutipan langsung dapat dilakukan jika:

- Kwatir jika menggunakan bahasa penulis sendiri, akan menimbulkan penafsiran yang berbeda. Misa;nya untuk perundang-undangan.

- $\quad$ Untuk mengungkapkan teori, dalil, rumus matematika serta rumus ilmiahlain.

- $\quad$ Ayat-ayat yang bersumber dari kitab suci atau hadist.

- $\quad$ Ingin mengomentari gagasan, ide dari penulis lain. Sehingga kita perlu mengngutipnya secara langsung.

- Tidak mungkin melakukan perasa, karena apa yang diungkapkan pengarang asli, telah cukup ringkas (Surachman, 2016)

\section{Menggunakan Parafrasa}

Apa yang dimaksud parafrasa. Parafrasa yaitu menyatakan suatu kalimat atau paragraf menggunakan kalimat yang berbeda darikalimat asli, dengan tidak mengubah maksud.Dalam parafrasa digunakan kosa kata yang berbeda dari kalimat aslinya.Ini merupakan bentuk pengutipan tidak langsung.Penulisan parafrasa tidak memerlukan 
tanda petik, namun tetap harus menyebutkans umbernya.Mengapa?Karena ide/gagasan dalam kalimat atau paragraf yang kitasusun kembali tersebut, merupakan ide, gagasan penulis pertama.

Walaupun kita membuat satu kalimat yang sangat berbeda dari kalimat yang kita gunakan untukmemparafrasa, tidak menjadikan kalimat tersebut merupakan buah karya kita. Dapat dikatakan bahwa parafrasa merupakan suatu cara menggunakan ide penulis lain dengan tetap menunjukkan kejujuran intelektual.Ketrampilan membuat parafrasa ini akan sangat bermanfaat bagi penulis, agarterhindar dari plagiarisme dan menghindari terlalu banyak menggunakan kutipanlangsung. Pembuatan parafrasa akan melatih penulis untuk berkreasi secararedaksional, karena dituntut ketrampilan dalam merumuskan kembali danmenuangkan dalam suatu kalimat yang berbeda.. (Zukarnainn, 2012)

Dalam penulisan sumber kutipan dengan sistem nama-tahun harus mengakomodasi berbagai variasi pustaka yang berkaitan dengan penulis, tahun terbit dan jenis pustaka, yaitu: jumlah penulis dari satu tulisan, jumlah tulisan yang dikutip dari penulis yang sama yang diterbitkan dalam tahun yang berbeda, jumlah tulisan dari penulis yang sama yang diterbitkan pada tahun yang sama, kemungkinan dua orang penulis mempunyai nama akhir yang sama, tulisan yang dibuat atas nama lembaga, tulisan tanpa nama penulis, jenis pustaka apakah berupa buku, jurnal, atau sumber lainnya, dan bentuk. Pustaka apakah berupa cetakan atau laman internet. Setiap sumber pustaka yang dikutip kemudian disusun dalam sebuah daftar pustaka dengan format tertentu.

Terkait dengan kutipan, beberapa organisasi mengeluarkan gaya atau model kutipan masing - masing yang disesuaikan dengan bidang- bidang kajianya. Beberapa contoh model atau gaya kutipan yang ada adalah:

\section{- APA Styles}

APA sendiri merupakan kependekan dari American Psychological Association, sehingga APA Styles merupakan salah satu bentuk kutipan yang dikeluarkan oleh organisasi APA terutama untuk bidang psikologi dan social. Beberapa ciri gaya penulisan kutipan diri APA Styles adalah:

1. Daftar Pustaka diurutkan alfabetis berdasarkan Nama Belakang Penulis atau judul apabila tidak ada penulis

2. Nama depan penulis ditulis sebagai inisial 
3. Apabila ada penulis sama dalam daftar pustaka ditulis berurutan dari tahun yang paling lama

4. Bisa ditambahkan huruf $a, b, c$ setelah tahun

- MLA Styles

MLA merupakan kependekatan dari Modern Language Association. MLA Styles merupakan slah satu bentuk kutipan yang dikeluarkan oleh MLA untuk sumber-sumber penilitian. Model MLA ini dirancang sangat sederhana untuk mempermudah penulisan dalam kutipan. MLA banyak digunakan untuk penulisan dalam bidang bahasa Inggris dan Humanities. Beberapa ciri dalam gaya penulisan MLA Styles adalah:

1. Nama penulis ditulis lengkap dengan nama belakng atau akhir dituliskan didepan

2. Tahun terbit diletakkan pada bagian akhir.

3. Kutupan pada halaman cukup dengan menulis kata akhir dan nomor halaman kutipan

4. Pada beberapa media tertentu dapat ditambahkan informasi jenis media dan format, misal cetak, online, web, dll.

5. Pada sumber online cukup menampilkan tanggal bulan dan tahun diakses tanpa menyebutkan sumber online nya. (Afriyana, 2002)

Contoh bentuk kutipan:

- Kutipan langsung pendek.

... Rilus Kinseng menjelaskan konsep jarak dominasi sebagai “... jarak spasial dimana dominasi nelayan 'kelas atas' terhadap nelayan 'kelas bawah' masih terjadi ...”

- Kutipan langsung panjang.

... mengenai motif migrasi suku-suku bangsa di Indonesia penulis setuju dengan pendapat Mochtar Naim sebagai berikut:

”... Kehadiran sejumlah besar orang-orang Bugis dan Banjar di daerah-daerah pantai Pesisir Timur Sumatera dan di Malaysia kelihatannya lebih bermotifkan ekonomi daripada dorongan sosial yang terbit dari sistem sosial mereka masing-masing di Sulawesi Selatan dan Kalimantan Selatan. Pengamatan yang dilakukan terhadap 
tradisi merantau di antara mereka tidak berhasil menemukan adanya jalinan yang kuat dalam sistem sosial mereka. Begitu juga halnya dengan orang Menado dan Ambon. ...”

Kutipan langsung harus ditulis sama persis dengan teks asli meskipun jika mengandung kesalahan. Jika penulis menemukan kesalahan dalam sumber aslinya maka penulis memberikan tanda [sic!], artinya penulis tidak bertanggungjawab atas kesalahan itu.

“... Demikian juga dengan data bahasa yang lain dalam karya tulis kami selalu berusaha mencari bentuk kata yang mengandung makan [sic!] sentral/terdistribusi yang terbanyak sebagai bahan dari daftar Swadesh....”

- Kutipan tidak langsung atau menggunakan parafrasa

1. Sumber kutipan ditulis oleh satu penulis.

a. Nama penulis dan tahun publikasi diletakkan di belakang kalimat atau terintegrasi dalam kalimat, misalnya:

•...bagi orang Minangkabau makna rantau sangat penting ... (Naim 1984).

- Naim (1984) menyatakan bahwa makna rantau bagi orang Minangkabau ...

b. Jika diperlukan untuk menyatakan nomor halaman dari sumber kutipan, maka nomor halaman itu dicantumkan di belakang tahun penerbitan dengan tanda titik dua. Contoh : (Naim 1984: 283) atau Naim (1984:283).

2. Sumber kutipan ditulis oleh beberapa penulis

a. Jika sumber kutipan ditulis oleh dua orang, maka di antara nama kedua penulis diberi kata 'dan'. Jika nama belakang kedua penulis sama, maka disertai dengan nama singkatan nama depan, sebagai berikut:

•(Wahyuni dan Kolopaking 2010) atau ... Wahyuni dan Kolopaking (2010)

- (Ehrlich PR dan Ehrlich AE 1990) atau Ehrlich PR dan Ehrlich AE (1990)

b. Jika sumber tulisan ditulis oleh lebih dari dua, hanya nama penulis pertama yang ditulis dan ditambahkan kata "et al." 3 atau "dkk" (kependekan dari 'dan kawankawan'). Pilih salah satu cara penulisan 'et al.' atau 'dkk', jangan bergantian dalam seluruh naskah. Sebuah tulisan oleh lima orang penulis yaitu: Mies Grijns, Inez Smyth, 
Anita van Velzen, Siti Sugiah Machfud dan Pujiwati Sajogyo yang diterbitkan pada tahun 1994, jika dikutip dalam naskah, maka sumber kutipan ditulis sebagai berikut: (Grijns et al. 1994)... atau ... Grijns et al.(1994)...

c. Jika nomor halaman penerbitan diperlukan untuk dikutip maka berlaku cara penulisan seperti yang telah dijelaskan sebelumnya. Contoh: Grijns et al. (1994:193). (Wahyuni, 2014)

$>$ Ketentuan Umum Menulis Daftar Pustaka

Dalam pembuatan daftar pustaka, selain kita harus paham unsur- unsurnya, kita juga harus mengetahui bagaimana ketentuan umum dalam menulis daftar pustaka. Jadi, tidak hanya urutan penulisan daftar pustaka saja yang diketahui . Berikut adalah ketentuan umum penulisan daftar pustaka:

- Hanya sumber rujukan yang disebutkan dalam teks utama yang dicantumkan dalam daftar pustaka.

- Referensi yang didapatkan dari hasil komunikasi personal, wawancara, dan sejenisnya, tidak perlu dicantumkan dalam daftar pustaka, kecuali jika hasil wawancara tersebut dimuat dalam suatu penerbitan.

- Daftar pustaka tidak perlu diberi nomor urut.

- Pengurutan daftar pustaka, ditulis berdasarkan nama penulis, urut abjad.

- Gelar penulis tidak perlu dicantumkan dalam daftar pustaka. Gelar akademis, gelar kebangsawanan maupun gelar keagamaan tidak dicantumkan. Sekalipun penulis mencantumkan gelarnya dalam bukunya yang kita kutip, tetapi kita tidak perlu mencantumkannya.

- Letak daftar pustaka adalah pada bagian akhir dari tulisan.

- Masing-masing sumber bacaan (yang terdiri dari dua baris atau lebih) diketik dengan jarak baris satu spasi.

- Jarak dari masing-masing sumber bacaan diketik dengan spasi dua.

- Baris pertama diketik tepat dari garis tepi (margin) paper, tanpa menggunakan indensi atau tidak menjorok. Lalu, untuk baris berikutnya pada satu sumber (jika satu 
sumber terdiri dari dua baris atau lebih), maka untuk baris kedua dan seterusnya menggunakan indensi empat atau tujuh ketukan.(Wijayanti, 2016)

Penulisan daftar pustaka masing-masing bidang ilmu disusun mengikuti pedoman yang dikeluarkan oleh organisasi internasional yang menerbitkan publikasi berkala.Cantumkan nama semua penulis bila tidak lebih dari enam orang penulis, tuliskan enam penulis pertama dan selanjutnya. Jumlah rujukan sebaiknya dibatasi sampai duapuluh lima buah dan secara umum merujuk pada tulisan yang terbit dalam satu dekade terakhir perlu dihindari penggunaan abstrak sebagai rujukan.

Materi yang telah dikirim untuk publikasi tetapi belum diterbitkan harus dirujuk dengan menyebutkannya sebagai pengamatan yang belum dipublikasi (unpublished observation) seizin narasumber.Makalah yang telah diterima untuk publikasi tetapi belum terbit dapat digunakan sebagai rujukan dengan perkataan “in press”.Hendaknya juga dihindari rujukan berupa komunikasi pribadi (personal communication), kecuali untuk informasi yang tidak mungkin diperoleh dari sumber umum. Sebutkan nama sumber dan tanggal komunikasi, dapatkan izin tertulis dan konfirmasi ketepatan dari sumber komunikasi. (Haryanto, 2008)

Daftar pustaka tidak dapat terlepaskan dengan sebuah karya tulis ilmiah. Darftar pustaka sebagia salah satu bentuk pengakuan intelektual penulis kepada penulis lain, atas rujukan yang digunakan. Dalam penulian daftar pustaka, beberapa istilah memiliki ketentuan sendiri. Demikian pula masing-masing penerbit jurnal, mereka memiliki gaya masing-masing dalam penulisan daftar pustaka. Gaya penulisan dftar pustaka, masuka dalam bagian dari gaya selingkung penulisan artikel penerbitan sustu jurnal.

Dengan demkian ketika akan mengirimkan hasil penelitian berupa artikel ilmiah kepada satu redaksi jurnal tertentu, penulisan harus memperhatikan gaya selingkung tersebut. Dan juga perlu diingat bahwa sitasi yang digunakan dlam teks, harus tertuang dalam daftar pustaka, demikan juga sebaliknya.Pembuatan daftar pustaka tentu ada fungsinya. Adapun fungsi daftar pustaka, yakni :

1. Memudahkan pembaca untuk mengetahui referensi lain yang dibutuhkan, yang tercantum dalam daftar pustaka.

2. Menunjukkan apresiasi atau penghargaan penulis terhadap karya orang lain yang dijadikan sebagi rujukan penulisan.

3. Memudahkan peninjauan ulang terhadap sumber pustaka yang dijadikan rujukan, atau 
sebagai koreksi.

4. Menunjukkan dasar pemikiran kita, sehingga tidak hanya mengesankan kita menulis tanpa dasar, atau sumber terpercaya.(Eko, 2013)

Tujuan penulisan sumber kutipan dan daftar pustaka:

1. Agar terhindar dari tuduhan penjiplakan (plagiarism)

Salah satu tujuan kutipan adalah untuk menguatkan atau mendukung tulisan ilmiah Anda. Oleh karena itu, Anda harus mencantumkan sumber kutipan Anda secara singkat di bagian akhir setelah kalimat kutipan atau tepat sebelum kalimat kutipan (paling dekat dengan kalimat kutipan) dan menuliskan sumbernya secara lengkap pada daftar pustaka. Dengan melakukan ini sebenarnya Anda sedang menghindarkan diri dari masalah di kemudian hari terkait dengan mengambil hak cipta karya tulis seseorang tanpa ijin.

2. Menghargai penulis sebelumnya

Ketika Anda menuliskan secara lengkap sumber kutipan dan daftar pustaka, sebenarnya Anda sedang menghargai orang yang mempunyai ide tersebut. Selain itu, juga pengakuan bahwa teks pada bagian tersebut adalah dari ide, argumen, dan atau analisa orang lain.

3. Membantu pembaca yang ingin tahu lebih dalam mengenai sumber kutipan

Salah satu manfaat dari menuliskan sumber kutipan dan daftar pustaka secara lengkap adalah membantu pembaca yang ingin mengetahui lebih dalam tentang kutipan tersebut. Kadang-kadang pembaca tertarik untuk membaca lebih dalam tulisan yang Anda kutip. Dengan demikian, pembaca dapat menelusuri informasi dari sumber kutipan dan kemudian mendapatkan rincian lengkapnya pada daftar pustaka. (Azariya, 2017)

$>$ Format Sitasi dalam Daftar Pustaka

Sama dengan sitasi di dalam teks, di dalam daftar pustaka, masing-masing model memberikan berbagai format sitasi di dalam daftar pustaka. Seperti juga format di dalam teks, disini dicontohkan format sitasi di dalam daftar pustaka, sesuaimodel APA (American Psycological Association).

1. Buku

Untuk urutan penyebutan unsur-unsur pustaka untuk buku ialah: Nama penulis, Tahun terbit, Judul Pustaka beserta keterangannya, Tempat terbit atau kota terbit, Nama penerbit. Jika tidak terdapat nama penulis dalam buku tersebut urutan penyebutan 
adalah: Nama lembaga yang bertanggungjawab, Tahun terbit, Judul pustaka beserta keterangnnya, tempat terbit, dan nama penerbit.

Setiap unsur pustaka dipisahkan oleh tanda titik, kecuali unsur tempat terbit yang diikuti oleh titk dua dan unsur nama yang harus dipisahkan oleh tanda koma. Setelah tanda titik atau setelah titik dua ada jarak satu ketukan. Contoh penulisan unsur pustaka acuan yang berupa buku diatur sebagai berikut :

a. Nama penulis

Nama penulis ada yang terdiri dari satu unsur, dua unsur, atau lebih dari dua unsur. Ketentuan pencantuman nama penulis adalah sebagai berikut:

1) Pencantuman nama penulis berdasarkan abjad, tanpa diberi nomor. Misalnya, jika nama penulis buku yang pertama Prof. Dr. Sumardjono dan nama penulis buku yang lain Dr.Ir. Baihaki, pencantuman dalam daftar pustaka adalah : Sumardjono, Baihaki.

2) Jika nama penulis buku terdiri atas dua unsur atau lebih, pencatumannya harus dibalik, unsur nama yang terakhir ditulis terlebih dahulu, kemudian tanda koma, diikuti unur nama didepan dengan disingkat. antara tanda koma dengan singkatan unsur nama diberik jarak 1 (satu) ketukan. Misalnya, pengarang buku yang diacu Abdul Haki dan pengarang buku lainnya Teodorus Albert Wenas, pencantumannya dalam daftar pustaka adalah: Haki, A. Wenas T. A.

3) Jika penulis buku tersebut dua orang, nama penulis pertama dibalik, tetapi nama penulis lainnya tidak dibalik. Misalnya, jika penulis buku itu adalah Kabul Santoso dan Rudi Wibowo, penyajiannya adalah:Santoso, K dan R. Wibowo.

4) Jika penulis buku terdiri dari tiga orang atau lebih, penyajiannya adalah nama penulis pertama dibalik, nama pengarang kedua, ketiga dan seterusnya ditulis tanpa dibalik. Misalnya: Idris, Z.husin, A. Tohari dan M. Singarimbun.

5) Jika penulisnya tidak ada, yang pertama dicantumkan adalah nama lembaga yang menerbitkan buku tersebut. Misalnya: Lembaga Administrasi Negara.

6) Jika ada dua buku atau lebih yang diambil dari pengarang yang sama, penulisan nama pengarang cukup sekali, sedangkan pada buku yang kedua nama pengarang diganti dengan garis terputus-putus sepuluh ketuk mesin ketik yang diikuti tanda titik. Misalnya : 
Farida, Ida. 1995. Budidaya Lebah Madu. Jakarta: Gramedia.

......... 1996. Budidaya Tanaman Kedelai. Jakarta: Gramedia.

7) Kalau buku yang diacu disusun oleh seorang editor, dibelakakng nama pengarang ditulis kata Ed. Misalnya: Koentjaraningrat (Ed)

8) Gelar kesarjanaan tidak dituliskan dalam daftar pustaka. Gelar keturunan masih dapat dipakai. Mislanya, nama pengarang adalah Prof.Dr. Raden Mas Soegondo, penulis nama daftar pustaka adlaah: Soegondo, Raden Mas.

b. Tahun terbit.

1) Tahun terbit ditulis setelah nama pengarang, dipisahkan oleh titik dan diakhiri dengan titik. Misalnya : Syahrani, Ridwan. 1990.

2) kalau dua buku ditulis oleh seorang pengarang, penyusunan urutannya berdasarkan tahun terbit yang terdahulu, misalnya :

Sutiana, Dadi. 1986. 1989

3) Kalau dua buku yang diacu ditulis oleh seorang pengarang dalam tahun yang sama, dibelakang tahun itu harus dibutuhkan huruf a dan b sebagai pembeda. Misalnya:

Muhammad, Suhedi. 1980a. $1980 b$

4) Jika buku yang diacu tidak berangka tahun, dibelakang nama pengarang diberi keterangan tanpa tahun. mislanya : Yusrial (tanpa tahun)

c. Judul buku

Judul buku ditulis sesudah tahun terbit dan diberi garis bawah atau cetak miring.Setiap huruf awal kata, kecuali kata tugas, ditulis dengan huruf kapital. Misalnya: Kridalaksana, Harimuri.1990 Kata Tugas dalam Bahasa Indonesia atau Kridalasana, Harimurti. 1990. Kata Tugas dalam Bahasa Indonesia

d. Tempat terbit 
Tempat terbit atau kota terbit diletakan sesudah judul dan diakhiri dengan titik dua:Suhono, Budi. 1986. Ular-Ular berbisa di Jawa. Jakarta:

e. Nama penerbit.

1). Nama penerbit dicantumkan sesudah nama terbit. Misalnya :

Suhono, Budi. 1986.Ular-Ular berbisa di lawa. Jakarta: Gramedia Pustaka Umum

2). Jika lembaga peenrbitan buku itu langsung dijadikan pennganti nama pengarang karena nama pengarang tidak ada, nama peenrbit tidak disebutkan lagi sesudah nama tempat terbit. Misalnya :Panitia Istilah Manajemen Lembaga PPM. 1990. Himpunan Istilah Manajemen. Jakarta.

3) Jika pustaka acuan belum diterbitkan, misalnya disertasi dan makalah setelah pencantuman judul diberi ketreangan makalah (belum diterbitkan).

Misalnya: Mulyono, Rakhmad. 1987. Peranan Departemen Pekerjaan Umum dalam Pembangunan Nasional. Makalah (belum diterbitkan) pada seminar (lokakarya) (Susanto, 2010)

2. Pustaka acuan berupa ontologi.

a. Jika sumber acuan berupa ontologi dan yang diacu bukan tulisan editor, urutan penulisannya adalah nama pengarang, tahun terbit, judul tulisan, yang diacu diberi tanda petik, judul ontologi diberi garis bawah atau cetak miring, tempat terbit dan nama penerbit. Setelah pencantuman judul tulisan diberi kata Dalam. Misalnya: Junus, U. 1986. "Kebudayaan Minangkabau". Dalam Koenjaraningrat (Ed.). Manusia dan kebudayaan di Indonesia. Jakarta: Djambatan.

b. Jika yang diacu adalah tulisan editor, urutan penulisannya adalah nama pengarang, tahun terbit, judul ontologi diberi garis bawah atau dicetak miring, tempat terbit dan nama penerbit. Misalnya :

Koenjaraningrat (Ed.). 1986. Manusia dan Kebudayaan di Indonesia. Jakarat: Djambatan. (Ropianto, 2018)

3. Pustaka acuan berupa majlah atau jurnal.

Sumber acuan yang diambil dari majalah dan jurnal urutan penulisannya dalam daftar 
pustaka adalah nama pengarang, tahun terbit judul artikel diberi tanda petik, nama majalah dicetak miring atau diberi garis bawah dan keterangannya serta didahului kata Dalam, bulan terbit, tahun penerbitannya yang keberapa, tempat terbit dan nomor halaman. Misalnya:

Gadalla, B.J. 1981. "Professional Record for ESL Learners"Dalam Forum. (April, XIX). N0. 2 Jakarta: The Embassy of the United States of America p. 34-48.

4. Pustaka acuan berupa media masa/majalah/surat kabar.

Jika sumber acuan diambil dari artikel dalam surat kabar ata media masa, urutan pencantumannya dalam daftar pustaka adalah nama pengarang, tahun terbit, judul artikel diberi tanda petik, nama surat kabar/majalah dicetak miring atau digaris garis bawah dan didahuui kata Dalam, tanggal terbit, tempat terbit dan halaman pemuatan artikel. Misalnya:

Simanungkalit, T. 1987. “Demokrasi Kita Masih Belajar di Tingkat Dua). Dalam Prioritas. 4 Mei. Jakarta: halaman 4-5.

5. Pustaka acuan berupa terjemahan

Bila sumber aacuan merupakan karya terjemahan penulisannya sebagai berikut: Martienez, A. 1987. Ilmu Bahasa. Pengantar. Terjemahan rahayu Hidayat dari Elemen de Lingusitique General (1980).Yogyakarta : penerbit kanisius.

Semua dokumen yang dikutif dalam laporan penelitian (dipublikasikan atau tidak) serta penelitian lainnya harus ditulis pada bagain akhir laporan yaitu daftar pustaka. Penulisan dfatar pustaka harus mengkuti standarisasi baku dan cukup rinci sehingga pembaca dapat dengan mudah mencari sumber asli dari kutipan yang ada pada laporan riset tersebut. Daftar pustaka perlu dibuat berurutan mengikuti urutan alfabetis berdasarkan abjad nama pengarang buku, artikel ilmiah, laporan riset ataupun artikel lainnya. dalam urutan abjad itu, buku yang dicetak menduudki kelompok pertama, kemudian jurnal menduduki urutan kedua sedang ketiga adalah kelompok pustaka yang tidak diterbitkan (skripsi, tesis, disertasi masuk dalam kelompok ini). (Safitry, 2016) 


\section{DAFTAR PUSTAKA}

Afriyana, S. (2002). Petunjuk Sitasi Serta Cantuman daftar Pustaka Bahan Pustaka Online. Pusat Perpustakaan dan Penyebaran Teknologi Pertanian, 54.

Amaliah, M. A. (2017). PEMANFAATAN JURNAL ELEKTRONIK SEBAGAI SUMBER REFERENSI DALAM PENULISAN SKRIPSI DI INSTITUT PERTANIAN BOGOR. LIbraria, Vol.5, No.1, 5-10.

Azariya, S. (2017). Tata Cara Penulisan Daftar Pustaka. Metode-metode Penelitaian , 24.

Eko, S. (2013). Cara pembuatan daftar pustaka baika dan benar. Yogyakarta: Suaka Media.

Fatchiyah. (2016). Strategi Penulisan Artikel Jurnal IImiah. Malang. UB Press.

Handoko, I. A. (2016). Mengelola Referensi Publikasi Ilmiah. Padang : Lembaga Pengembangan Teknologi Informasi dan Komunikasi (LPTIK).

Haryanto. (2008). Metode Penulisan Dan Penyajian Karya Ilmiah. Jakarta: Penerbit Buku Kedokteran EGC.

Istiana, P. (2013). Membuat Sitasi dan Daftar Pustaka . Materi Pelatihan Kursus Pelatihan Instruktur Literasi Informasi. Universitas Padjajaran Bandung, 27.

Kalsum, U. (2016). Referensi sebagai layanan, referensi sebagai tempat: sebuah tinjauan terhadap layanan referensi di perpustakaan perguruan tinggi. Jurnal Iqra', 133.

Kistan. (2018). Teknik Manajemen Referensi dan Layout Karya Tulis IImiah. Yogyakarta: Grup Penerbitan CV BUDI UTAMA.

Nugroho, R. A. (2015). Mudah Membuat Referensi \& Bibliografi. Yogyakarta: PENERBIT DEEPUBLISH (Grup Penerbitan CV BUDI UTAMA).

Purwoko. (2017). Menggunakan Zotero untuk mengelola referensi. ditulis untuk pelatihan di UNISA, 1-7.

Ropianto, M. (2018). Membuatan Dartar Pustaka. WORKSHOP PEMBUATAN SITASI DAN DAFTAR PUSTAKA BAGI MAHASISWA PROGRAM STUDI TEKNIK INFORMATIKA SEKOLAH TINGGI TEKNIK(STT) IBNU SINA BATAM, 45.

Safitry, D. (2016). Pebedaan antara Bibilografi dan daftar pustaka. Bandung. Penerbit 
Informatika.

Surachman, A. (2016). Gaya Tulisan Sitiran Karya Ilmiah. Perpustakaan Gajah Mada, 14.

Susanto, L. (2010). Kiat Jitu Menulis dan Menerbitkan bauku. Jakarta: Erlangga.

Wahyuni, E. (2014). Pedoman Teknik Penulisan Laporan Studi Pustaka. Lampiran POB MK Studi Pustaka, 36.

Wasmana. (2011). Penulisan Karya Ilmiah. modul, 45.

Wijayanti, H. (2016). Pengertian Daftar Pustaka. visi Pustaka, 60.

Zukarnainn. (2012). Menghindari perangkap plagiarisme dalam menghasilkan karya tulis IImiah. Yogyakarta: Penerbit Kanisius. 